DOI https://doi.org/10.30525/978-9934-26-180-0-4

\title{
THE UKRAINIAN BORROWINGS IN FICTION TEXTS WRITTEN BY V. KOROLENKO
}

\author{
Namachynska H. Ya. \\ Doctor of Philosophy, \\ Associate Professor at the Linguistic \\ and Intercultural Communication Department \\ Istitute of Foreign Languages \\ Drohobych Ivan Franko State Pedagogical University \\ Drohobych, Lviv region, Ukraine
}

The Ukrainian language has a tradition of functioning as a donor language that affects the enrichment of lexical semantic and stylistic resources of the Russian language. There is a need to define the features of development the Ukrainianisms in Russian, it is necessary to develop the appropriate methods of their qualifications and to represent the Ukrainian borrowings in Russian in a particular lexicographical source. Of course, the Ukrainian borrowings in Russian as a consequence of the appropriate interlingual contacts have some tradition of the research and fixing in lexicographical sources (Interpretative Dictionary of "Great Russian" Language by V. Dahl, Dictionary of Modern Russian Language) but there is no dictionary of the Ukrainian borrowings in the Russian language.

A great number of scholars study borrowings in different languages: in Ukrainian (B. Azhnyuk, D. Barannik, N. Dybyiak, Y. Zhluktenko, T. Kosmeda [1], T. Kyyak, L. Kochan, L. Matsko, O. Styshov, L. Struhanets, etc.), Russian (V. Aristov, E. Volodarska, L. Wilkens, L. Krysin [5], A. Larionov, A. Mayorov, A. Molodkina, O. Solohub, O. Shakhraiy), English (B. Hansen, H. Hitchings, A. Stanforth, S. Thomson), Italian (I. Chelysheva), German (R. Brunner, H. Fink, M. Lenhert), Polish (V. Blanar, T. Lehr-Splawinski), French (B. Hak) and the others.

The goal of the scientific research is to find out the Ukrainian borrowings in fiction texts written by V. Korolenko.

Material of the research - the stories "The Blind Musician" and "The Children of the Dungeon" by V. Korolenko.

Memories of the childhood and teenage years spent in Ukraine were always dear and close for him. The Ukrainian themes and images were highly imprinted ("The Blind Musician", "The Children of the Dungeon", "Wood Murmurs", "No Tongue"). 
The Ukrainian borrowings of the Russian language belong to the artifacts the names of the musical instruments, including bandore, kobza, lire [3]. The same with the category of people who play these instruments - a bandore player, a kobza player, a lire player, who were usually blind. Kobza, bandore and lire are symbols of the Ukrainian folk-lore, the Ukrainian history. V. Korolenko emphasizes the function of a bandore player, a kobza player, a lire player and their role in life of the Ukrainian people. As we can see in these texts there are also other types of the Ukrainian borrowings: lexical and grammatical form of address - khlopets'. The onomastic Ukrainian borrowings - the names Ukraine, Poltava, Kniazh-horodok, Kyiv, Cherkasy, the Ukrainian borrowings folklorism - a wide world ( $a$ wide world means a wide space), the lexical and semantic Ukrainian borrowings - the names of traditional Ukrainian phenomena, events, reality (fair, house, Cossak's grave).

In "The Children of the Dungeon" we found out such Ukrainian borrowings as pan, haydamak, khlopets', khokhol, chub, chupryna and the others [4]. However, it should be specified that chub and chupryna do not have the same meaning as some people think, but they are two different types of hairstyles.

Fiction texts written by V. Korolenko led to the enrichment of the Russian socio-cultural context, to the stabilization of cultural and linguistic norms. The theme of the works led to the use of multicultural language tools, among which a special place is occupied by the Ukrainian linguistic component. Reflecting the Ukrainian reality, the author used a verbal indirect description, in which the key elements are the Ukrainian linguistic and cultural signs, the Ukrainian borrowings, original inclusions of the Ukrainian song-poetic or colloquial language. The above mentioned Ukrainian borrowings are fixed in the Dictionary of the Russian language by V. I. Dahl.

\section{References:}

1. Космеда Т. Аксіологічні аспекти прагмалінгвістики: становлення та розвиток категорії оцінки: монографія / Львів, 2000. ЛНУ імені I. Франка, 350 с.

2. Короленко В. Г. Шумить ліс (Польська легенда). Збірка оповідань. М, 1956. Художня література. Т. 2. С. 70-120.

3. Короленко В. Х. Сліпий музикант. М, 1956. Художня література. T. 2. C. $122-170$.

4. Короленко В. Х. Діти підземелля. Харків, 2013. 445 с.

5. Крисін Л. П. Иноязычные слова в современном русском языке. M, 1968. Наука. 208 с. 